\title{
China’s Urbanization Drive and Its Consequences: The Jimo Case
}

\begin{abstract}
Han Dongping
Warren Wilson College

One million Chinese villages have disappeared in the three decades since the beginning of China's rural reform, one third of the total. As a result of this urbanization, China can no longer produce enough grain for itself. In 2012, China imported 80 million tons of grain, which is about $12 \%$ of its total grain need. Now the new Chinese Government inaugurated in 2013 has stepped up its push for more urbanization. Many more rural villages throughout China have been dismantled or will be dismantled at a crazy pace. China's environmental degradation will surely further deteriorate. This paper is a case study about urbanization and its social, economic, and environmental consequences in China.
\end{abstract}

Keywords: urbanization, displacement of farmers, the three fold crisis of rural areas, farmers and agriculture, environmental degradation, dismantling of rural houses

\section{Introduction}

For the last century or so, capitalist development has occurred at great expense to agriculture and rural areas in the whole world. This process has resulted in a great decline of rural areas dependent on agriculture and bankrupted many farmers. Many small farmers lose land and have to migrate to urban areas. In the United States, some aspects of this process have been depicted in the literary works like Sister Carrie (Dreiser 1900), The Jungle (Sinclair 1906), and A Thousand Acres (Smiley 1991). As a result of declining rural areas, only $2 \%$ of people in the U.S. today are farmers, who produce about only $1 \%$ of U.S. GDP. Because of the small farming population, American agriculture mostly relies on large machineries, chemical fertilizers, pesticides, and herbicides; the environmental impact of modern agriculture is apparent. Because the overwhelming majority of the Americans reside in urban areas and suburbs, food and other resources have to be shipped to them. The packaging and shipping of these resources all contribute to environmental crisis we are faced with today. Urban populations produce huge amounts of garbage in their life, and processing this garbage causes more environmental damage. Many problems such as unemployment, homelessness, drug addiction, mental illness, crime, and gun violence are in one way or another connected with the gradual decline of rural areas and agriculture and the bankruptcy of farmers. The social and environmental challenges created by this modern way of life threaten the long term survival of human race. The continued use of large machinery, chemical fertilizers, pesticides, and herbicides has long-term negative impact on agricultural productivities. Despite of its abundant agricultural resources, American food security may not be as secure as it looks.

Han Dongping, guest professor of Hebei University, professor of History and Political Science at Warren Wilson College, USA; main research field: China’s Rural Development. 
In Third World countries, the consequences of declining agriculture have been even worse. The U.S. and West have been pushing green revolution technology upon them, with devastating consequences for societies in the Third World. Small farmers lose their land and have to migrate to urban areas, ending up in shanty towns or homeless. The urban centers of many Third World countries like Mexico, India, Philippines, and Brazil have crowded shanty towns and large homeless population-these have become insurmountable problems facing Third World countries today.

\section{Maoist Rural Development Model}

During the first 30 years of the People's Republic of China, the socialist Government, which represented the fundamental interests of workers and farmers, made an effort to avoid the disastrous consequences of unplanned urbanization taking place throughout the world, particularly in the Third World countries. Through the radical land reform movement, followed by the collective farming movement, China had successfully avoided a decline of its countryside, displacement of its rural population, and agricultural bankruptcy: the so called "three-fold crisis" of agriculture, farmers, and rural areas. From 1949 to 1976, when Chairman Mao died, the Chinese population had risen to 800 million, almost doubling, and the Chinese people's life expectancy had increased from 35 years in 1952 to 69 years in 1976, almost doubling as well, leading India, a country with similar social economic conditions in 1952, by almost 20 years ("Health Care during Mao Era," 2012; Yundan Shuinuan 2006). During this socialist era, China solved many long lasting social vices like banditry, prostitution, drug addiction, human trafficking, rampant crimes, and official corruption through full employment in the urban areas (Xiao 2014). With the collective farming arrangements, Chinese farmers gained full employment, access to free education, and free medical care (Han 2001). By promoting rural education and reforming the country's college education system, the Chinese government effectively stalled the brain drain from rural to urban areas, as common throughout the world. In fact, the Chinese government reversed the normal flow of talents by encouraging 17 million educated urban youth to work in the countryside before and during the Cultural Revolution years. The ability to retain native talents and absorb urban talents enabled the Chinese rural areas to develop a green revolution of their own, without much outside input (Han 1999). I say "encouraging” to describe the phenomenon of the urban youth going to the countryside, because no other words would accurately capture the essence of the movement of the time. I understand that many people, including some of the urban youth who went to the countryside at the time, look back at the movement with regret, and some call the urban youth the lost generation. When the Chinese Government reintroduced the college entrance examination in 1977, discarding the previous college student selection system, many of the sent down urban youth naturally felt betrayed and victimized by the sending down movement at the time. I interviewed many urban youth who went to the countryside both in the U.S. and in China. Most of them told me candidly that they went enthusiastically, and some went unwillingly but took it for granted because everybody else, including high official's children, went. China's new president Xi Jinping spent eight years, and Chinese Premier Li Keqiang spent six years in the countryside (Interviews with Sent down Youth in Boston and New York, 1996; Interview with Sent down Youth in Zhengzhou, 1997). (When I told my students in class that 17 million urban youth volunteered to work in countryside during the Cultural Revolution years, my students could not believe it without the benefit of grasping the social climate of the time and era. One of my students said to me that it must be with a gun at their head. To that student, I answered. Of course it must be with a gun at their heads. How could Chinese young people be willing to do good for others without a gun at their heads? But how do we 
explain American young people's response to President Kennedy's call to volunteer in the Peace Corp in the third world? Why could the Chinese Youth answer to their leaders' call to volunteer in the countryside? Our campus has a volunteer work day once a year. Almost everybody participates. It has been taken for granted by the community. People who doubt the possibility of Chinese young people volunteering for the public good represent a bias of western cultural supremacy. In fact, the whole ideas of volunteerism or service originated from former Soviet Union and Socialist China.)

In most Third World countries, the implementation of the green revolution from the U.S. and West resulted in bankruptcy of small farmers, displacement of poor farmers, and emergence of large shanty towns in big urban centers. In China, the native-grown green revolution brought about increased grain production and improved livelihoods for everybody across the board: Nobody was left out of the benefit of green revolution because of the collective farming arrangements (Han 2013). The development of rural industry in the vast Chinese countryside absorbed the surplus rural population which the mechanization of agriculture freed up. Chinese rural population was able to engage in urban employment without leaving their native land. I personally managed a collectively owned village factory which employed 173 people for four years before I went to college in 1978. There were other collectively owned non-agricultural enterprises in my village beside the main factory I was managing at the time. More than one half of the village's labor force was engaged in non-agricultural employment in 1970s. Every village in Jimo County had more than one industrial project in the 1970s. Because of the development of collectively owned rural industrial projects in rural areas, farmers did not need to look for employment in the urban areas and farmers' incomes were on the rise every year in the 1970s because of the income from industry. As the village collectives became financially well off, villages were able to provide better educational opportunities for their populations and free medical care for everyone.

By avoiding the unplanned urbanization, China also minimized the environmental degradation accompanying the modernization efforts throughout the world. The rural collectives processed all human, animal, and kitchen waste, turning them into organic fertilizers. Because Chinese farmers were producing grain mostly for themselves, they did not need any packaging for their products. Chinese farmers also bought vinegar, soy sauce, and wine with their own bottles, effectively reducing the need for packaging of most commercial products. In the 1970s, each village had a collective mill, which can process grain for everybody in the village, which eliminated all the need for packaging and shipping. Because everybody in the community had an equal stake in their shared environment, people took care of their environment more consciously-without an environmental movement at that time. For that reason, some experts of international development refer to China as the model for Third World countries and hope for the human race (Pepper 1996).

Some environmentalists in the U.S. and west tend to blame our environmental problems on poor people. Judith Shapiro, the author of Mao's War against Nature, is an extreme example of this (Shapiro 2001). She literally interpreted some of the Chinese conventional wisdom like ren ding sheng tian (people will master nature) to mean that humans fighting against nature. Like many other people in China with ulterior motives, Shapiro misquoted Mao's words. Maybe her misquotation was not intentional. I have no way to know. Mao's words came from his article written in 1917, when he was only 24 years old, and long before he became a revolutionary or revolutionary leader, and four years before the Chinese Communist Party was even founded. His original words were: yu tian fen dou, qile wuqiong, yu di fen dou, qile wuqiong; yu ren fen dou, qile wuqiong. It was “fen dou," not dou, which means something completely different. Tian and di do not mean nature either. Tian (sky) refers to things that beyond human understanding and control, and di (earth) refers to 
things that human understand and something they can control. Mao wrote that piece at the age of 24 as a philosophic reminder for himself, not to fight a war against nature, but as a lifelong objective to enjoy the challenges by known and unknown forces and enjoy working with similar minded people to build a better world (Wang Haoquan 2008). The Chinese right-wing scholars have intentionally misquoted and misinterpreted Mao's original words because they wanted to tarnish Mao's model of development.

Chinese people under the leadership of Mao built more than 80,000 reservoirs to improve irrigation. They also worked hard to improve the soil of their land, like terraced field to increase grain yield. As a result, China was able to feed more than $21 \%$ of world population with only $7 \%$ of world's arable land. As a result, China largely solved the famine problems plaguing the Third World country, even some of the First World country. It is simply absurd for people like Shapiro, who enjoyed food security, to condemn the Chinese people's heroic effort to secure their own food security with their own hand.

\section{The First Wave of Urbanization in China}

When Deng Xiaoping broke up China's rural collectives in 1982, which forced Chinese farmers to farm their own tiny share of land individually, Chinese farmers were no longer able to defend their collective ownership of land. Urbanization started growing uncontrollably. In the last thirty-some years, urbanization in China has been driven not by public good, but by corruption and profiteering at the public expense. Village leaders were bribed to sell the collective land to the government first at a nominal price. Private entrepreneurs bribed the government officials to develop the land. The government officials got the bribery; the government got the difference of buying and selling prices, and capitalist got the profit from the development of the land. Thus, it has been the chain of corruption that has fueled the growth of urbanization in China. As a result, developers became richer and richer, and farmers lost their means of existences in rural areas. They had to migrate to the urban areas to survive. According to some estimate, one million villages have disappeared in China in the last three decades, about one third of the total. Currently more than eighty villages disappear each day (China Newsweek, October 4, 2013). Hainan Island alone lost two thousand villages in the last 20 years (Quang Changxun and Shao Changchun 2013).

There are 1,050 villages in my hometown: Jimo County, Shandong Province. Before the first wave of urbanization in 1982, every village had enough land to grow sufficient amounts of food to support its population, with some surplus to sell to the state to support the tiny urban population at the time. In the last three decades, about three hundred villages, close to one-third of the total, lost all or most their land to urban development. The remaining two-thirds lost part of their land to commercial and industrial development as well. The 53 villages in the former Chengguan Commune, most of the 57 villages in the former Yingshang Commune, most of the 25 villages in former Sanlizhuang Commune, and most of the 36 villages in former Xiapo Commune, have lost most of their land. The former Dianji Commune, former Aushang commune, and former Jinkou Commune on the coast witnessed great urban development in the last 30 years. Capital from Hong Kong, Taiwan, and the U.S. have been competing for the limited space on the coast to build hotels, residential buildings, and shopping centers. Shandong University, based in Jinan, Haerbin University of Military Technology, based in Haerbin, Heilongjiang Province, and the Beijing Xiehe Hospital, based in Beijing, all carved up several-thousand mu farmland each to build their branch campuses on the coast areas. Some American entrepreneurs also started building their own production facilities on the coast in my hometown. Local officials have been very excited about these urban development projects because they have 
brought money to their townships. They do not take into consideration the long term social, economic, and environmental impacts of these urbanization projects on the rural population (Interview with Local Officials in Aoshan Township, 2012).

\section{The Social, Economic Impact of Break-up of the Collective and Urbanization}

As urbanization spread, many farmers lost their land and means of living; some of the landless farmers had to struggle to survive. Villages endowed with good public assets were able to provide their villagers with some necessities, three fifty-jin bags of wheat flour, one bag of rice, and one ten pound bottle of cooking oil annually. Some well-off villages were also able to provide senior villagers a two-to-three thousand yuan per year subsidy (Interview with Farmers in Jimo, 2012). Those in villages without public assets have had to fend for themselves (Interviews with Villagers in Jimo, 2012). Sadly, they were in the majority: villagers without any support from the village have to find work in the urban sector or sell small items on the market to make a living. Throughout China, about two hundred million migrant farmers have been working in the urban areas, mostly in construction and factories, leaving their families behind. They were fueling the construction boom in China throughout the 1980s, 1990s, and 2000s. Most of these migrant farmers were treated very badly in the cities. They did not have any governmental protections and they were not well paid. Some of the contractors did not pay workers on time or in full. Some even fled with workers' salaries, which often became huge social issue in the 1990s and 2000s. This treatment of migrant farmers in urban areas has created tremendous social instability in the last 30 years (Interview with Farmers in Jimo, 2012). The efforts by the migrant workers to get paid often resulted in riots and attacks on government offices.

The migrant farmers who are working in the urban areas often left their children behind in their village, because these migrant farmers do not take permanent residence in the urban areas. They usually reside in temporary shelters on construction sites. There are simply no educational or child care facilities for the migrant workers' children. The cost of taking their children with them to the urban areas is beyond their means. As a result, over 60 million Chinese children have been left behind in rural areas while their parents work in urban areas. This has become a serious social problem in China (VOA, 2014). When a nation fails to take care of their children, it will have to pay a high price in the end.

Crime is on the rise because many farmers cannot find jobs to support themselves. In a village in Jimo, where there were no crimes during the ten years of the Cultural Revolution, several dozen people had turned to crime to make a living. Many young people have joined criminal gangs because they could not find jobs. They help businesses collect debts by violent means. They would beat up rivals of the private capitalists who were willing to pay for their service. For a number of years, these criminal gangs were willing to serve as hit-men for hire. They would break a leg or an arm, or cut off an ear of the targeted persons for a sum of money (Interview with Gang Members in Jimo, 1998).

In one of the villages I studied, there was a group of thieves operating mostly outside the village that picked pockets in the marketplace, broke into urban hotels to steal valuables, and collaborated with thieves in the big cities. The local informants would identify a corrupt official or a rich man. With the information, these criminals would break into the house to take whatever valuables they could and divide up the goods with the urban collaborators. Over the years, some of these people were caught by the police and had to serve time in prison, but the majority of them were able to continue to live as thieves. 
I studied a village in Henan Province for the last 30 years. There are a little over three thousand people in the village today. For more than 10 years during the Cultural Revolution years, there had been no "crime" in the village. But since the reform, over two hundred people, almost $10 \%$ of the population, have served time in prison. The county's public security bureau used to have only 36 police officers before 1982. Today, there are over five hundred police officers in the same public security bureau. But it has been so overwhelmed with crimes that the police no longer investigate thefts and other petty crimes. They have to concentrate on more serious crimes like murders and robberies (Interview with Police Officers Henan, 2005).

In 1994, there were 49 arsons in less than two months in this Henan village, almost two for every three days. Villagers were so scared that they reported the arsons to the police, who came to investigate and then asked the village to pay for the cost of gas and provide food and lodging. The police questioned more than two dozen young people in the village whom they considered suspects, but in the end they had to let every one of them go. The police were not able to arrest anybody for these arsons even though they stayed in village for over sixty days. As a result of these arsons, villagers were living on the edges. They did not dare to leave their houses at night, fearing that someone would set their house on fire while they were away (Interview with Farmers in Henan, 1995). The same people had lived in the same village: With collective farming they were able to enjoy peace and serenity. Without the collectives, they were victimized by chaos and crimes. The transition was dramatic.

After the breakup of the collectives, the public education and health care systems in the Chinese countryside collapsed. Before the breakup of the collectives, villages paid schoolteachers and barefoot doctors with work points. School teachers and barefoot doctors in turn got grain and other living necessities from the collective with their work points, like everybody else in the village. When the collective broke up, it was no longer possible to pay teachers and barefoot doctors with work points. At the same time, the Central Government's investment in the rural areas declined dramatically in the 1980s, from close to $15 \%$ to barely $5 \%$ of the national budget, as the government shifted its focus from reducing the gaps between the rural and urban areas to modernizing its industry and urban development. Rural schools began to charge parents' tuitions for children in elementary schools and middle schools. The number of high schools was greatly reduced throughout rural China: Many counties had only one or two high schools and less than $20 \%$ of middle school graduates were able to get into a high school. Now the Chinese Government claimed that it provided compulsory primary and middle school education in the countryside. People do not need to pay tuitions for children in primary and middle school any more. But they still have to pay fees and other cost. But compulsory education does not include high school yet at this time. Those who are able to get into a high school have to pay outrageously high tuition, often more than ten thousand yuan a year, higher than most rural parents could afford. That is another reason that many farmers have to migrate to urban areas to work to earn money to support their children's education, and many teenagers who are out of school join the migration from rural to urban (Interview with Farmers in Henan and Shandong, 1994; 2010).

The rising educational cost coincided with the hiking of prices for production materials like chemical fertilizers, pesticides, and diesel fuel. Farmers had to struggle to survive: Many of them did not have extra cash to pay for their children's education. As a result, a large number of rural children, particularly rural girls, lost access to education in the 1980s and 1990s. I started doing rural research in mid-1980s in Henan Province. I was shocked to see the large number of illiterate children in the rural areas, because just a few years ago, every child was in school. What I saw in the countryside in the mid-1980s inspired me to write my dissertation on 
rural education. While attending graduate school, I volunteered for the Zigen Fund based in New York City for a number of years, collecting donations to support the rural girls' education in China. I went to rich American individuals and companies with connections in China to raise money to pay tuition for rural children. I traveled to Guizhou, Hebei, and Henan to see the educational conditions in rural areas. I was dismayed to discover that charity was not the answer to the educational problems in China: The solution had to come from the state, as it was the state policy that created the situation. It was not just about the money. China was much poorer during the Cultural Revolution years, but China was able to provide a free education for all of its children. China was supposedly richer during the reform era, but it was no longer able to provide its rural children a free education. The Chinese government has been accepting charity from its own citizens and foreign countries to provide educational opportunities for the poor segments of its population which the government calls the "hope projects.”

During the Cultural Revolution years, every village had a clinic with a few barefoot doctors providing villagers with free, convenient medical care. That was one of the reasons why the Chinese people's life expectancy had been almost doubled from 35 in 1952 to 69 in 1976. These barefoot doctors were not well-trained. They were usually high school graduates. The village collective sent them to the hospitals to get their basic training, usually three to six months at the first stage. When the first one came back, a second one was sent for training. A village with two thousand people would usually have four or five barefoot doctors. They took turns to get more advanced training while providing basic medical care and medical education for the villagers. During the busy times, the bare foot doctors would go out to the fields to provide care for farmers working in the fields. The barefoot doctors only provided basic medical care and basic medical education for the farmers. For more complicated problems, patients would be referred to the commune or county hospitals where they were covered by the cooperative medical care system (Interview with Farmers in Henan and Shandong, 1995).

Many people liked to downplay the importance of barefoot doctors for their lack of training. Technically, they were not as good as the better trained doctors in the urban areas, but that was the best the Chinese farmers could get at the time. More importantly, the barefoot doctors had some advantages that the better trained urban doctors did not have. They were from the same village as their patients and sincerely cared for their patients' wellbeing. They knew their patient's family and background very well. They were available 24 hours a day, seven days a week, and they were right in the same village. That was something that the better-trained urban doctors could not compete with the barefoot doctors. My father used to work for a state owned factory and therefore enjoyed free medical care provided by the state through the urban hospital free of charge. But my father would rather use the service of the barefoot doctors in the village where we lived at the time. He argued that the better trained doctors in the hospital did not care as much about him as an individual compared with the barefoot doctors who he knew on a personal basis. For big problems, he had no choice but to go to the big hospitals, but for small problems, he would rather go to the barefoot doctors instead.

The barefoot doctor system was one of the best innovations of the Chinese people during the Cultural Revolution years: It provided an effective solution to the public health problems in China. The barefoot doctors played an irreplaceable role in improving the Chinese rural people's health and life expectancy during the Cultural Revolution years.

When Deng Xiaoping broke up the collectives, the barefoot doctor system, like its sister institution of rural public schools, collapsed as well. Hundreds of millions of rural Chinese lost access to free medical care in the 
last 30 years. It has become a serious crisis in China. When I was attending graduate school at Brandeis in the early 1990s, a professor in the Heller School of Public Policy told the class one day that the Chinese Government commissioned the faculty of Heller school to design a good public health program for China for one million dollars. He commented that the Chinese Government's move was ridiculous for two accounts. First, it apparently did not know that the United States of America could not solve the public health problems of its own. Second, China used to have one of the most effective medical care systems in the world suitable for its environment and social economic conditions. The Chinese elites were eager to learn everything from the U.S. but they did not really know what was going on in the U.S.

With the collapse of the cooperative medical care system in the Chinese countryside, Chinese farmers lost access to affordable medical care. Most Chinese farmers I interviewed told me that they would not seek medical treatment if they were sick. If it was a small problem, it would take care of itself in time without treatment. If it were a big problem, it would be too costly to seek treatment. They did not want to overburden their children with a big debt. One of the farmers I interviewed told me that his neighbor, whom I also interviewed, sought medical treatment for his heart problem. He borrowed money from everyone he could and ended up with a debt close to two hundred thousand yuan, but died from a heart attack two years later. Now his two sons would have to pay back the debt all their life. This farmer thought that what his neighbor did was stupid and he would never do that to his own children (Interview with Farmers in Henan, 2003).

In response to the mounting medical cost, the Chinese government has been trying to bring back a cooperative medical insurance system in the Chinese countryside. But many Chinese farmers I interviewed viewed the medical care with a lot of doubt and the effects therein remain to be seen.

Most students of Chinese politics would think the pictures I presented here about the Chinese countryside during the Cultural Revolution years to be too cozy. How about the pictures presented in the scare literature published after the Cultural Revolution was officially denounced in China? How about the persecution of doctors described in the novel and movie To Live (Yu Hua 2004)? Yu Hua was writing fiction, which can or cannot be based on the author's or someone's life experiences. But it is wrong to assume what happened in the scar literature are all really happened. Even if what described in To Live was true, it could not negate the accomplishments of the Cultural Revolution. My writing is based on my own life experiences during that time, and the stories of farmers who lived through these times.

\section{The Environmental Consequences of the Urbanization}

The environment was the biggest victim of the large scale urbanization drive over the last 30 years in China. During the socialist time, the collectives took good care of their environment. At that time, most Chinese farmers lived a garbage-free life style. The collective had assigned special teams of people to collect all the night soil from every household, and fermented them into organic fertilizers. Kitchen waste, night soil, animal waste, and weeds from the fields were all gathered and fermented to be used as organic fertilizers. In many locations, the methane gases produced in the fermenting process were captured and used to illuminate homes and cook meals. Managing these wastes required a lot of hard work and energy. The collectives were able and willing to invest the time and energy in these activities because it was good for the environment and it was good for the survival of the community (Interview with Farmers in Shandong, 2012).

During the socialist era, the Chinese production was planned. There was no overproduction of anything and there was no competition amongst different producers for the market share. These state owned enterprises 
were not producing for profit - they were producing to make sure that people's needs were being met. That was the most essential difference between socialism and capitalism. Most Chinese state-owned firms at the time sold their products in bulk and without unnecessary packaging. As a result, there was little to no waste in people's life. At the same time, Chinese people would recycle small pieces of metal, glass, and paper. When China practiced socialism, it had no inflation for 30 years. The price of products only went down, never up. But as soon as China adopted the so called market reform, inflation went up several dozen times over a span of thirty years. In 1984 alone, Chinese government printed more money than its previous 30 years combined (Interview with Farmers in Shandong and Henan, 2011).

The Chinese farmers used very little chemical fertilizers and pesticides in their fields during the collective era of 1970s, partly because these things were not easily available at the time. They did not use any herbicides either. They controlled weeds in the fields mostly through hoeing on a regular basis. It was hard and time consuming work, but it was an effective way of farming. Hoeing did not only control the weeds in the fields; it also served to conserve moistures in the soil. When the land was dry, hoeing would reduce evaporation by disturbing the surface soil. When the land was too wet, hoeing would dry the soil fast by loosening the surface soil. Some people estimated that the amount of moisture conserved through the practice of hoeing in northern China amounted to the volume of one Yellow River and two Hai River each year, a total of 89 Billion Cubic Meters (Meng “On the Social Genesis of Serious Water Shortage in Northern China”).

Because of the hoeing practices and other simple environmental practices of the collective era, the rivers in northern China were always running and protected. The Moshui River in my hometown was always clean and full of fish and shrimps at that time. People could drink the water in the river directly. In my childhood, swimming and ice skating in the river were very important after school activities for children. The river was the lifeline of the people in my hometown then.

With the urbanization over the last 30 years, the Moshui River became sewage quickly. Without the collective effort to collect and treat the night soil, animal waste, kitchen waste, the river became a convenient dump ground. In summer of 1998, I was so angered to see big piles of garbage in the river that I confronted a resident who was dumping garbage into the river with indignation. But the resident asked me very calmly. "Do you think that I want to put the garbage into the river? But I have to have a place to dump them, right? Tell me where should I dump it?” With his question, my indignation disappeared. He had a good point. People needed to have a place to dump their garbage. If the government did not provide a way to manage the garbage, people had to put the garbage into the river.

In the summer 2005, I went to the county environmental bureau in Jimo, supposedly the biggest of its kind at the county level, to talk about the pollution in the river. I was told that the government was overwhelmed by the environmental challenges it faced from the large scale urbanization, and it took time for the government to respond to the environmental crises. However, a solution was on the way, said one of the officials who received me. The government had assembled a budget of two hundred million yuan to deal with the pollution of the river. By the next summer, he promised me, there would be a river as clear and clean as the one from my childhood. I was overjoyed to hear his statement. But the next summer, I went back home to find the river as bad as before even though the money had been spent. I realized then that with urbanization and corruption, it was no longer possible to have clear and clean rivers.

People in my hometown were able to take care of the river and the environment when they were organized and when they worked together as a community. Now that they are competing in the market place to make 
more money, they are no longer able to take the right actions to protect their common environment, upon which their own survival ultimately depends.

Such has been the fate of every river in Jimo County, every river I have seen in Shandong Province, and every river I have seen in Henan Province and Hebei Province. Even the great mother river, Yellow River, is dry for a significant part of the year now. In the last 30 years, a bigger and bigger percentage of the Chinese population has adopted the urban life style with running water in their houses. They began to shower on a daily basis and began to have flushing toilets. To provide these modern amenities, the Chinese had to take more and more water from underground. When I was young, we were able to reach the underground water table in less than two meters. Now, it will have to go close to one hundred meters to reach underground water table in Jimo. An article in The Economist claimed that the water table had dropped three hundred meters in Beijing (Economist, October 12, 2013). Chinese farmers no longer hoe their land to control weeds and moisture in the soil. Instead, farmers used herbicides to control weeds and rely on irrigation, which requires more water from underground. In the face of serious natural disasters like water shortage, the Chinese people and Chinese Government need to wake up very quickly.

\section{The Food Security and Related Health Issues}

Food security is another crisis resulting from large scale urbanization in the last 30 years. During the collective era, most Chinese farmers were producing what they ate from their own land. Their dependence on food from outside of their region was minimal. The use of chemical fertilizers and pesticides were more regulated and more guided through the centralized network of training and expertise. Each village had a technical experiment team whose job was to test the new seeds, new fertilizers, and new pesticides before they were used in larger fields. This team also went to get training and acquire new skills from the upper-level government and then passed the skills and knowledge onto other people in the village. With the breakup of the collectives, the centralized network of training and expertise collapsed. Each individual farmer is now on his own, especially to learn about the new chemical fertilizers and new pesticides. Accidents are frequent with the use of field chemicals, particularly pesticides. When I was doing rural research in Shandong, Henan, and Anhui Provinces over the last 30 years, I was told that the emergency rooms during the busy seasons were often filled with poisoned farmers who had come in contact with pesticides. The unsafe levels of residue on the crops harmed people's health throughout China. People in China talked about how vegetables like ginger, garlic chives and many others became too toxic for human consumption. There were also rumors that Chinese farmers would not eat vegetables and grain produced for the market. They only ate grain and vegetables grown without the use of pesticides. Chinese Central TV actually aired a report this summer about an interview with a farmer in Shouguang who told the reporter that they did not eat the ginger they grew for the market because it was too toxic.

In the 1990s, when I was interviewing farmers in Henan rural areas, some farmers advised me not to eat in the small restaurants around the train stations. They told me that villagers would collect all the dead animals in the rural areas and processed them and then sold them to the meat dealers in the urban areas and eventually ended up in the small restaurants throughout China. Several families in that village were engaged in such business and several truckloads of dead animals were processed on a daily basis. During the collective era, these kinds of illegal operations would be forbidden by the village collective. But now nobody cared (Interview with Farmers in Henan, 1995). 
As more and more people stopped producing food for their own consumption, processed food becomes more common in China. With the increase of processed food, the number of additives to the food is on the rise as well. To compete in the competitive markets for more profits, some people use all kinds' chemical additives to make their products look better, taste better, and so on. I have talked with officials in Shandong Provincial Food Security Bureau about the additives in the processed food. They said that they were overwhelmed with the problem. There were too many small food processers out there. The number of additives in processed foods, the known ones of which were in the hundreds already, was expanding very rapidly. Also, the sample products companies send in for tests often differed from the products which were actually put on the market. The whole situation was very chaotic and it was simply impossible for the government to manage and control these additives into processed food (Interview with Food Security Officials in Shandong, 2012).

For the sake of profit, Chinese producers have produced in the last 30 years poisonous milk powders which resulted in the death of dozens of children and caused a panic among parents in China with some international implications. Chinese parents' desire to buy milk powders in Hong Kong led the Hong Kong local government to limit the number of jars of milk powder customers can buy. Australian and German milk powder producers increased the price of their products on the Chinese market to take advantage of the situation. Poisonous meat also appeared in Chinese markets and led to the increased import of American meat to China. The Chinese Shuanghui Meat Processing company purchased Smithfield, the biggest American meat producers, partly because of Chinese people's concern about the meat safety in China. There are also reported that capitalists used industrial alcohol to make liquor with damaging impact on human health. One liquor dealer told me candidly in an interview that most of the liquors he sold were fake products; otherwise he could not make any profit (Interview with Liquor Merchants in Shandong, 2013).

The food safety crisis naturally connects with human health. Death rates in rural areas have been on the rise since Deng Xiaoping's rural reform. There can be many reasons behind the rise of death rates in the Chinese rural area, like the mental stress related to the new competitive social climate, and the rising concern for the survival of one's family, but food safety must be an important factor as well. More and more rural people have contracted diseases which are unknown and rare to the rural areas, like diabetes, heart attacks, high blood pressure, and strokes, which are also related to environmental degradations. Chinese government statistics indicated that China's life expectancy has increased by almost five years since the reform, in 2000, 20 years after the reform (China.net, 2012). Some people challenged the government's statistics about the increase of life expectancy in China; some scholars argued that China's rural population's life expectancy was 12 years shorter than that of the urban population (Zhongwei 2005).

From the villages I know in Shandong and Henan, I believe that the number of people dying young in the rural areas has increased significantly in the last 30 years. I started working with villagers in 1964. By the time I left the village to go to college in 1978, I do not remember anybody dying young in these 14 years, except one person killed by an accident and another by suicide. But during the last 30 years, many people have died young. Of the forty-some people I worked with in the early days of my life, eight of them died in their thirties and forties. Three out of four of my high school classmates in one village died before they were fifty years old: I am not sure of the statistical significance of this.

China's food security faces another crisis. In 1978, China was able to produce enough grain to feed its people. At the time, China exported some rice and imported wheat from abroad because the price of wheat was significantly lower than rice. As China loses more land to urbanization, and as more land is laid waste, as more 
farmers migrate to urban areas as a result of deteriorating conditions in the countryside, China is becoming more dependent on imported grain for survival. In a recent debate about the safety of GMO grain, Scientist Wu Kongming, who is an authority on GMO committee of Chinese Academy of Science, argued that China imported 80 million tons of grain each year annually, which equaled 800 million mu of land. Therefore, he believed that China does not have the right to reject GMO grain any more (Wu 2013). He must have miscalculated about the figure of 800 million mu of land. China's average yield per mu is about three hundred kilo, and 80 million ton grain would translate into about 100 million mu of land. China produced about 550 million tons of grain by itself, and 80 million ton is about $11 \%$ of China's national food need. That is on the basis of good harvest for the last nine years. China's food security has been on a dangerous trend. In time of natural disasters, China's future ability to provide for its own people will be questionable.

\section{Current Wave of Urbanization}

The recently inaugurated Chinese leadership team, particularly Premiere Li Keqiang, is determined to put China's urbanization into overdrive. Local governments throughout China are engaging in dismantling farmers' houses to build new high rise apartment buildings in response to the Central Government's call for chengzhenhua (urbanization). They used many excuses, like improving local transportation, sanitation, building safety, and so on, to dismantle farmers' traditional houses with courtyards. By dismantling farmer's one story houses, the local government will be able to build many more apartment units on the same land. They will be able to make a lot of money by selling these apartments to the people who could afford to move to these high rise buildings (Interviews with Farmers in Jimo, 2013). They are doing this in complete disregard of Chinese government laws and the basic standards of human rights of the United Nations.

This last summer, I witnessed in Jimo City, Shandong Province, a large-scale dismantling of farmers' houses by the local government. In a matter of 20 days, 4,798 farmers' houses in ten villages were dismantled by the local government. On the ground previously occupied by one-story traditional houses which had an accumulated cultural legacy of three thousand years, high-rising apartment buildings, usually 36 stories, will be built in the next two-and-a-half years. At least, that is the promise of the local government. Most farmers did not want to give up the houses they had been living in for generations. But they feared what the government would do to them if they refused to move. Therefore, most of them signed an agreement to leave even though they did not want to (Interviews with Famers in Jimo, 2013).

A year earlier, Yaotou village collectively opposed the government's plan to dismantle their village with the excuse to improve local transportation, but the City Government intervened by replacing the village party chief with someone who supported the dismantling of the village. In the end, the government sent in six hundred police officers to force villagers to sign the agreement to move. The village chief who was elected by the villagers stood up to defend the houses and was beaten by criminal elements hired by the developers and police just watched refusing to lend help to the victims of the criminal violence. In the end, only ten families still refused to sign the agreement to move. But one night, criminal elements came into their houses, put a hood over their heads, and forcefully dragged them out of the houses and then dismantled their houses forcefully (Interviews with Farmers in Jimo, 2013).

Three years ago, Xiejiaying and Houyangtou villages were dismantled by the local government. About one hundred villagers from the two villages organized to resist the government decision to dismantle their houses. In the end, the criminal elements broke the legs of one of the organizers of the resistance and another organizer 
was kidnapped. He was put into a bag and left on the beach. The criminal elements also threw explosives and snakes into the houses whose residents refused to move. In the end, all these people were forcefully removed and their houses were dismantled. The government promised the villagers that they should be able to move back to the new apartment buildings in two and half years, but the developers did not finish the construction of the new apartment buildings in time. In fact, construction has been suspended because the developers have exhausted their fund and have fled, leaving the villagers hoping to move back in despair (Interviews with Farmers in Jimo, 2013).

Nine years ago, villagers resisted collectively when Datong and Fangzijie villages were about to be dismantled by the local government. The government's effort to dismantle these two villages was stalled by the resistance. But the upper government sent a new Party Secretary to Jimo. He came with three hundred criminal elements hired from his hometown in Chengyang. These criminal elements put a temporary metal sheet wall around the villages and began to terrorize the villagers with brutal force. These acts were shielded from public sight. Villagers' resistances fell apart and the two villages were dismantled. Now nine years later, on the grounds of the two villages, it stands several 36 stories apartment buildings, unfinished. The government officials who had started the project have long been promoted to some other post. They took briberies from the developers themselves. But the developers did not have the money to even pay their suppliers. They had to pay their suppliers in kind with apartments. The sale of the apartment buildings did not go well either, because the people who had the money to buy them had more than enough apartments already. The people who needed an apartment to live in could not afford to buy one. The government had to buy the surplus apartments from the developers, which led to another serious problem in China today: the debt burden of the local government (Interviews with Farmers in Jimo, 2013).

Most of this dismantling and building has been driven by profiteering. In order to get these development projects, developers often have to bribe the local officials. The local officials needed money to bribe their superiors in order to get promotions. Therefore, the local officials provide the developers with the opportunities, and developers provide the local officials with the money needed to buy higher positions. That has been the reason why the Chinese government officials are so eager to push for the urbanization called for by the central government. In the eyes of many local officials, this is one of the most important opportunities to get money. Most people in Jimo I talked to believed that the urbanization was driven by officials' desire for more money from developers (Interviews with Farmers in Jimo, 2013).

When I was leaving my hometown at the end of summer in 2013, five thousand more houses in 10 other villages were designated for destruction and rebuilding, including the home where I spent the first 23 years of my life. The government came to ask for my permission to dismantle my house. I told them that it was my house and I would sue whoever dismantles it without my consent in the United States. I knew it was a bluff, but it worked for the time. As a result, my house was still standing while all other houses were leveled.

If the current urbanization continues, in a few years there will be no real villages left in China. The rural life as the Chinese farmers know will be gone forever. The sociopolitical impact of this dramatic change for the longest-surviving nation in the world with a continuous written history will be hard to fathom at this point.

Most Chinese farmers lived a very simple life with their traditional houses and courtyards. They usually had wells that they could pump water up with a hand powered pump. They grew their own vegetables in their yards. They lived a life of bare necessity without much electricity and many modern amenities. For the landless farmers who have little income, this is the only way of life they can afford. They do not want to leave their 
houses because they cannot afford to live in apartment buildings. They will have to pay more for water, electricity, elevators, and other costs involving the management of the buildings and the environment. They will not be able to grow their own vegetables any more. Many people will be hard pressed to survive.

The long term impact of urbanization in China is hard to estimate at this point. I would argue that the very survival of Chinese people and Chinese culture is at stake. China has survived the last five thousand years largely through small scale farming. Agriculture, farmers, and rural areas are the lifeline of the Chinese people. China only has one quarter of American's arable land, but with five times more people to feed. Urbanization in the last 30 years has already done horrific damage to China's environment. Continued urbanization will jeopardize the very survival of the Chinese people and the Chinese culture. The effect of urbanization is hard to undo. It is very hard for uprooted farmers to return to rural areas. Left to itself, the trend of urbanization will be hard to reverse. Chinese Government must increase its investment in rural areas to improve farmers' access to education and medical care. The gaps between urban and rural areas must be gradually eliminated for farmers to enjoy farming again. Many years ago, I called upon the Chinese government to invest more in collective farming to fight the three fold crisis of agriculture, rural areas, and farmers. I want to call on the Chinese government to end their drive for urbanization. Instead of bringing farmers to urban areas, they should bring the urban amenities, like urban education and urban medical care, to the rural areas. So, farmers do not have to migrate to the urban areas to improve their lives. Chinese population is already unevenly concentrated in the coast areas. More urbanization will cause more concentration of the population with more devastating environment consequence. Bringing the urban amenities to the countryside will be costly and only state can assume this cost. But it should be done for sake of the environment and for the survival of Chinese people and the Chinese culture.

\section{Works Cited}

Changxun, Quang and Changchun Shao. “Hainan Gucunluo Shuaibai (Ancient Hainan Villages Disappeared).” Tongxun Net. July 23, 2013.

“China’s Life Expectancy Reached 74.83, Increased 3.43 Years Since 2000.” China.net, August 10, 2012.

Dreiser, Theodore. Sister Carrie. Berlin: Townsend Press, 2004.

“Eighty Villages Disappear Each Day.” No. 719. China Newsweek. October 4, 2013.

“All Dried up, Northern China Is Running out of Water, but the Government Remedies Are Potentially Disastrous.” Economist. October 12, 2013.

“Health Care during the Mao Era.” iLook China, Looking at China from an Outsider's Point-of-View. August 14, 2012.

Han, Dongping. "Impact of Cultural Revolution on Rural Education and Development in Rural China.” Modern China 3 (2001).

---. “China’s Hukou System and Rural Development.” Journal of Developing Areas. 1999.

---. "Rural Agriculture: Scientific and Technological Development during the Cultural Revolution.” Chunjuan Nancy Wei and Darryl Brock, Mr. Science and Chairman Mao's Cultural Revolution. London: Lexington Books, 2013.

---. Interviews with Sent down Urban Youth in Boston and New York. 1996.

---. Interviews with Sent down Urban Youth in Zhengzhou. 1997.

---. Interview with Local Officials in Aoshan Township. Summer 2012.

---. Interview with Farmers in Jimo. Summer 2012.

---. Interviews with Villagers in Jimo. Summer 2012.

---. Interview with Gang Members in Jimo. Summer 1998.

---. Interviews with Police Officer in Anyang, Henan. Summer 2005.

---. Interview with Farmers in Henan. Summer 1995.

---. Interview with Farmers in Henan and Shandong. Summer 1994. 
---. Interviews with Farmers in Henan and Shandong. Summer 1995.

---. Interview with Farmers in Henan. Summer 2003.

---. Interview with Farmers in Shandong. Summer 2012.

---. Interview with Farmers in Shandong and Henan. Summer 2011.

---. Interview with Farmers in Henan. Summer 1995.

---. Interview with Food Security Officials in Shandong. Summer 2012.

---. Interview with Liquor Merchants in Shandong. Summer 2013.

---. Interviews with Farmers in Jimo. Summer 2013.

"Liushou Ertong Wenti (the Issue of Children Left behind in the Rural Area While Their Parents Working in the Urban Area).” VOA. Ferbruary 11, 2014.

Meng, Fangui. “Systemic Drought: On the Social Genesis of Serious Water Shortage in Northern China.” Meng Fangui ’s blog.

Pepper, Suzanne. Radicalism and Education Reform in 20th Century China: The Search for an Ideal Development Model. New York: Cambridge University Press, 1996. 1-20.

Shapiro, Judith. Mao’s War against Nature. New York: Cambridge University Press, 2001.

Sinclair, Upton. The Jungle. New York: Doubleday, Jabber \& Company, 1906.

Smiley, Jane. A Thousand Acre. New York: Ballantine Books, 1991.

Wu, Kongming. “Chinese Does Not Have the Qualification to Reject GMO.” Guangming, Tech GMW. CN. October 10, 2013.

Wang, Haoquan. "yu tiandou, yu didou, yu rendou qile wuqiong de qishi (the Inspiration from the Phrase of Fighting with Sky, Earth and People).” <http://blog.sina.com.cn/gdfwhq>. January 11, 2008.

Xiao, Hongsong. "Zhongguo jindai jindushi yanjiu de huigu yu qianzhan (An Review and Foresight on the Research of Modern Chinese History of Anti-Opium Movement).” Collection of Conference papers. HBU-IUP International Conference: The Research and Teaching of World History in a Global Age, July 1-4, 2014.

Yu, Hua. Huozhe (To Live). Shanghai: Wenyi Publishing House, 2004.

Yunduan Shuinuan. "Weida de yigai (1949-1978): Cong 35 sui dao 68sui (The Great Medical Reform (1949-1978): From 35 years to 68 years.” Club.dayang.com. October 3, 2006.

Zhao, Zhongwei. "Build Harmonious Social Environment: The Success and Challenge of Reducing Death Rate in China." November 17, 2005. 